\title{
Oxidative glutamate toxicity involves mitochondrial dysfunction and perturbation of intracellular $\mathrm{Ca}^{2+}$ homeostasis
}

\author{
Cláudia F. Pereira, Catarina Resende de Oliveira * \\ Faculty of Medicine and Center for Neuroscience of Coimbra, University of Coimbra, 3004-504 Coimbra, Portugal
}

Received 28 February 2000; accepted 13 April 2000

\begin{abstract}
Glutamate toxicity on PC12 cells is mediated by oxidative stress as a consequence of the inhibition of a cystine uptake system with depletion of GSH. In this study we report that glutamate decreases PC12 cell viability, inhibiting the reduction of 3-(4,5-dimethylthiazol-2-yl)-2,5-diphenyltetrazolium bromide (MTT). This decrease was prevented by the antioxidants vitamin E, idebenone and L-deprenyl, which were also shown to be effective in reducing the accumulation of reactive oxygen species (ROS) in cells exposed to glutamate, decreasing the fluorescence of $2^{\prime}, 7^{\prime}$-dichlorofluorescein (DCF). Incubation of PC12 cells with high glutamate concentrations induced mitochondrial dysfunction, leading to the loss of mitochondrial transmembrane potential, evaluated as a decrease in rhodamine 123 (Rh123) retention by mitochondria, and to the decrease of intracellular ATP levels. The mitochondrial dysfunction, induced by glutamate, can be involved in the observed increase of $\left[\mathrm{Ca}^{2+}\right]_{\mathrm{i}}$. The elevation of $\left[\mathrm{Ca}^{2+}\right]_{\mathrm{i}}$ occurred after GSH depletion, suggesting that oxidative stress is involved in the disturbances of intracellular calcium homeostasis. In conclusion, our data indicate that glutamate, at concentrations which block cystine uptake in PC12 cells leading to GSH depletion and inducing oxidative stress, increases ROS accumulation and decreases cell survival by a mechanism involving mitochondrial dysfunction and impairment of $\mathrm{Ca}^{2+}$ homeostasis. (C) 2000 Elsevier Science Ireland Ltd and the Japan Neuroscience Society. All rights reserved.
\end{abstract}

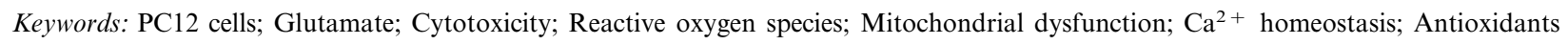

\section{Introduction}

Oxidative stress is thought to be related to various neurodegenerative conditions and disorders including ischemia-reperfusion, traumatic injury, Parkinson's disease (PD) and Alzheimer's disease (AD) (Kehrer, 1993; Jenner, 1994; Bolaños et al., 1997). The amino acid glutamate may induce oxidative stress in neurons and

\footnotetext{
Abbreviations: dbcAMP, dibutyryl cyclic AMP; DCF, 2',7'-dichlorofluorescein; $\mathrm{DCFH}_{2}, 2^{\prime} 7^{\prime}$-dichlorofluorescin; $\mathrm{DCFH}_{2} \mathrm{DA}, 2^{\prime}, 7^{\prime}$ dichlorofluorescin diacetate; $\Delta \psi_{\text {mit }}$, mitochondrial transmembrane potential; Fura-2, 1-[2-(5-carboxyoxazol-2-yl)-6-aminobenzofuran-5oxy]-2-2(2'-amino-5'-methyl-phenoxy)-ethane- $N, N, N^{\prime}, N^{\prime}$-tetracetic acid; GSH, reduced form of glutathione; LDH, lactate dehydrogenase; NGF, nerve growth factor; NMDA, $N$-methyl-D-aspartate; MTT, 3-(4,5-dimethylthiazol-2-yl)2,5-diphenyltetrazolium bromide; Rh123, rhodamine 123; ROS, reactive oxygen species.

* Corresponding author. Tel.: + 351-239-820190; fax: 351-239822776.

E-mail addresses: cpereira@cnc.uc.pt (C.F. Pereira)., croliveira@gemini.ci.uc.pt (C.R. Oliveira).
}

has been implicated in various neurodegenerative diseases (Coyle and Puttfarcken, 1993; Lees, 1993; Blandini et al., 1996; Obrenovitch and Urenjak, 1997).

Glutamate may be directly toxic to cultured neuronal cells via two different processes, both of which result in the production of free radicals. The classical pathway, known as excitotoxicity, occurs through the activation of NMDA and non-NMDA glutamatergic receptors (Olney, 1969) and subsequent calcium influx into the cell (Michaels and Rothman, 1990). The oxidative glutamate toxicity pathway is a transporter-mediated type of cell death (Murphy et al., 1989) that requires the cellular expression of the cystine/glutamate antiporter system (Bannai, 1986), that has recently been described in primary neuronal cultures (Bannai, 1986; Murphy et al., 1989, 1990; Oka et al., 1993; Davis and Maher, 1994), in neuronal cell lines (Kato et al., 1984, 1992; Murphy et al., 1989; Miyamoto et al., 1989; Davis and Maher, 1994) and in tissue slices (Schubert et al., 1992). The competition by glutamate for the cystine/glutamate 
antiporter induces an imbalance in the homeostasis of cystine, the precursor of glutathione (GSH). Therefore, the inhibition of cystine uptake by the constant and high exposure to glutamate is supposed to give rise to an inability to maintain intracellular GSH levels, leading to a reduced ability to protect against oxidative injury of the cell and, ultimately, cell death. The accumulation of an excess of free radicals seems to be responsible for the toxicity, because this second pathway can be blocked by antioxidants (Miyamoto et al., 1989; Davis and Maher, 1994).

Recently, we have demonstrated, in agreement with other authors (Vornov and Coyle, 1991; Froissard and Duval, 1994), that exposure of PC12 cells to high doses of glutamate decreases its survival (Pereira and Oliveira, 1997). Furthermore, we have reported that glutamate toxicity is prevented by several antioxidants, suggesting that the mechanism of cell damage induced by glutamate is mediated by the increased generation of free radicals. This mechanism involves the inhibition, by glutamate, of a plasma membrane cystine uptake system and the depletion of GSH levels, resulting in cell damage by its inability to remove free radicals. GSH has been demonstrated to detoxify hydroperoxides including the $\mathrm{H}_{2} \mathrm{O}_{2}$ formed during the oxidative metabolism of dopamine (Murphy et al., 1990). The results of Maher and Davis (1996), demonstrating a role for monoamines in glutamate toxicity, may provide an explanation for glutamate toxicity on a rat pheochromocytoma-derived PC12 cell line, which consists of a homogenous population of dopamine containing cells that have been demonstrated to synthesize, store and release dopamine in a similar manner to neurons (Greene and Rein, 1977).

The aim of the present study is to further define oxidative glutamate toxicity, frequently used as an oxidative stress paradigm (Behl et al., 1992, 1997; Calderón et al., 1999), by determining the effect of prolonged exposure of PC12 cells to high glutamate doses on the mitochondrial function and calcium homeostasis. It is clearly demonstrated that high glutamate concentrations induce cell death through a mechanism involving an increase in the levels of reactive oxygen species (ROS) as a consequence of intracellular GSH depletion, which leads, through mitochondrial dysfunction and perturbation of intracellular $\mathrm{Ca}^{2+}$ homeostasis, to cell death.

\section{Materials and methods}

\subsection{Chemicals}

L-Deprenyl was obtained from RBI (MA, USA). Monosodium L-glutamate, dibutyryl cyclic AMP (dbcAMP), 3-(4,5-dimethylthiazol-2-yl)-2,5-diphenyltetrazolium bromide (MTT), and D- $\alpha$-tocopherol succinate were purchased from Sigma (USA). The 1-[2-(5- carboxyoxazol-2-yl)-6-aminobenzofuran-5-oxy]-2-(2'amino-5'-methyl-phenoxy)-ethane- $N, N, N^{\prime}, N^{\prime}$-tetracetic acid, penta-acetoxymethyl ester (Fura-2/AM), 2',7'dichlorofluorescin diacetate $\left(\mathrm{DCFH}_{2}-\mathrm{DA}\right)$, and $\mathrm{Rh} 123$ were purchased from Molecular Probes Inc. (Eugene, OR). GSH-400 colorimetric kit was obtained from Bioxytech (France). ${ }^{45} \mathrm{Ca}^{2+}$ was purchased from Amersham International (Amersham Centre, UK). All other reagents were of analytical grade. Idebenone was a generous gift from Seber, Portugal.

\subsection{Cell culture and analysis of glutamate toxicity}

Stock cultures of PC12 cells (Greene and Tischler, 1976) were grown routinely in RPMI 1640 medium supplemented with $10 \%$ heat-inactivated horse serum and $5 \%$ heat-inactivated fetal calf serum, to which penicillin $(50 \mathrm{U} / \mathrm{ml})$ and streptomycin $(50 \mu \mathrm{g} / \mathrm{ml})$ were added, and maintained at $37^{\circ} \mathrm{C}$ in a humidified incubator containing $95 \%$ air and $5 \% \mathrm{CO}_{2}$. For differentiation, cells were plated on poly-L-lysine-coated $(10 \mu \mathrm{g} / \mathrm{ml})$ 24-well dishes $(0.5 \mathrm{ml} /$ well $)$. Twenty-four hours after seeding, cells were washed twice in RPMI 1640 medium and differentiation was induced by adding $50 \mathrm{ng} / \mathrm{ml}$ of nerve growth factor (NGF $2.5 \mathrm{~S}$ ) plus $1 \mathrm{mM}$ dibutyryl cyclic AMP (dbcAMP). The medium was changed every 2 days and after 7 days in culture, in the presence of NGF and dbcAMP, cells were used for toxicity studies.

Twenty-four hours after seeding, the medium was renewed by fresh medium containing the desired glutamate concentration. When antioxidants were tested, cells were simultaneously incubated in the presence of glutamate and $10 \mu \mathrm{M}$ vitamin $\mathrm{E}(\alpha$-tocopherol-succinate), $500 \mu \mathrm{M}$ L-deprenyl or $1 \mu \mathrm{M}$ idebenone. Vitamin $\mathrm{E}$ and idebenone were previously preincubated for $24 \mathrm{~h}$ before glutamate addition (and maintained during glutamate exposure) in order to allow the incorporation of these antioxidants in biological membranes. After the desired incubation period, the culture medium and/or the cells were analyzed for MTT reduction (Mosmann, 1983). In brief, MTT was dissolved in PBS at $5 \mathrm{mg} / \mathrm{ml}$ and was 10-fold diluted in serum-free RPMI 1640 medium. After incubation of the cells with the compounds to be tested, the medium was aspirated and MTT $(0.5 \mathrm{mg} / \mathrm{ml})$ containing serum-free medium was added. After an additional $3 \mathrm{~h}$ incubation at $37^{\circ} \mathrm{C}$, isopropanol $/ \mathrm{HCl}$ was added to each well and the absorbance of solubilized MTT formazan products was measured at $570 \mathrm{~nm}$.

\subsection{Measurement of intracellular ROS formation}

Formation of intracellular peroxides was detected with a fluorescent spectrophotometer using a non- 
fluorescent compound, 2',7'-dichlorofluorescin diacetate $\left(\mathrm{DCFH}_{2}-\mathrm{DA}\right)$, which is de-esterified within cells by endogenous esterases to the ionized free acid, $2^{\prime}, 7^{\prime}$-dichlorofluorescin (Bass et al., 1983). 2', $7^{\prime}$ Dichlorofluorescin is capable of being oxidized to fluorescent $2^{\prime}, 7^{\prime}$-dichlorofluorescein (DCF) by hydroperoxides. After exposure to glutamate, with or without antioxidants, the cells were incubated in $2 \mathrm{ml}$ of 140 $\mathrm{mM} \mathrm{NaCl}, 5 \mathrm{mM} \mathrm{KCl}, 1 \mathrm{mM} \mathrm{MgCl}, 5.6 \mathrm{mM}$ glucose,

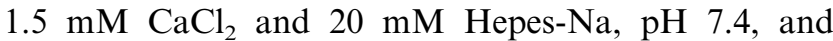
allowed to take up $5 \mu \mathrm{M} \mathrm{DCFH}{ }_{2}-\mathrm{DA}$ at $37^{\circ} \mathrm{C}$ for 20 min, in an atmosphere of $95 \%$ air and $5 \% \mathrm{CO}_{2}$. After loading with $\mathrm{DCFH}_{2}$-DA, cells were washed with the same buffer and fluorescence was measured at $502 \mathrm{~nm}$ excitation and $550 \mathrm{~nm}$ emission.

\subsection{Analysis of mitochondrial membrane potential}

The changes in mitochondrial membrane potential $\left(\Delta \Psi_{\text {mit }}\right)$ were estimated using the fluorescent cationic dye Rh123, which accumulates in mitochondria as a direct function of the membrane potential and is released upon membrane depolarization (Palmeira et al., 1996). After exposure to glutamate, the cells were incubated for $10 \mathrm{~min}$ at $37^{\circ} \mathrm{C}$ with $\mathrm{Rh} 123(1 \mu \mathrm{M})$, in an atmosphere of $95 \%$ air and $5 \% \mathrm{CO}_{2}$. Cells were then washed with $140 \mathrm{mM} \mathrm{NaCl}, 5 \mathrm{mM} \mathrm{KCl}, 1 \mathrm{mM} \mathrm{MgCl}_{2}$, $5.6 \mathrm{mM}$ glucose, $1.5 \mathrm{mM} \mathrm{CaCl}_{2}$ and $20 \mathrm{mM}$ Hepes-Na (final $\mathrm{pH}$ 7.4) and transferred to a fluorometer cuvette. The dye remaining trapped in the cells was determined by fluorimetric analysis at excitation and emission wavelengths of 490 and $515 \mathrm{~nm}$, respectively, at $37^{\circ} \mathrm{C}$. Triton X-100 was added in order to disrupt the cells and establish the maximum retention of Rh123.

\subsection{Analysis of adenine nucleotides}

After the incubation period, the medium was removed and PC12 cells were extracted, in ice, with $0.3 \mathrm{M}$ perchloric acid. The cells were scraped from the wells and centrifuged at $15800 \times g$ for $5 \mathrm{~min}$. The pellets were solubilized with $1 \mathrm{M} \mathrm{NaOH}$ and analyzed for total protein content (Sedmak and Grossberg, 1977). The supernatants were neutralized with $10 \mathrm{M} \mathrm{KOH}$ in $5 \mathrm{M}$ Tris and centrifuged. The resulting supernatants were assayed for adenine nucleotides by separation in a reverse-phase HPLC, as described by Stocchi et al. (1985). The chromatographic apparatus used was a Beckman System Gold, consisting of a 126 Binary Pump Model and a 166 Variable UV detector, controlled by a computer. The column used was a Lichrospher 100 RP-18 $(5 \mu \mathrm{m})$ from Merck. An isocratic

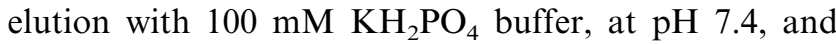
$1 \%$ methanol was performed at a flow rate of 1.2 $\mathrm{ml} / \mathrm{min}$. The adenine nucleotides were detected at 254 $\mathrm{nm}$, for $6 \mathrm{~min}$.

\subsection{Measurement of intracellular calcium} concentration, $\left[\mathrm{Ca}^{2+}\right]_{i}$, and determination of ${ }^{45} \mathrm{Ca}^{2+}$ uptake

The concentration of intracellular $\mathrm{Ca}^{2+}$ was measured with Fura-2/AM, a calcium fluorescent ester chelator and indicator (Di Virgilio et al., 1988). After glutamate incubation, cells were harvested by gentle scraping, washed and resuspended in a standard medium containing $140 \mathrm{mM} \mathrm{NaCl}, 5 \mathrm{mM} \mathrm{KCl}, 1 \mathrm{mM}$ $\mathrm{MgCl}_{2}$, $5.6 \mathrm{mM}$ glucose, $1.5 \mathrm{mM} \mathrm{CaCl}$ and $20 \mathrm{mM}$ Hepes-Na (final pH 7.4), which was used for loading and for the subsequent fluorescence measurements (Liu et al., 1991). Fura-2/AM $(5 \mu \mathrm{M})$ was added to the cell suspension, which was subsequently incubated for 30 min. The cells were then washed, resuspended in the standard medium and transferred to thermostatically controlled cuvettes equipped with a magnetic stirrer. The fluorescence intensity of Fura-2 was quantified with a fluorescence spectrophotometer, with a single excitation wavelength set at $340 \mathrm{~nm}$ and an emission wavelength monitored at $510 \mathrm{~nm}$ (Vrasenic and Knöpfel, 1991). $\left[\mathrm{Ca}^{2+}\right]_{\mathrm{i}}$ was calculated from the fura-2 fluorescence intensity using the equation: $\left[\mathrm{Ca}^{2+}\right]_{\mathrm{i}}=$ $K_{\mathrm{D}}\left(F-F_{\min }\right) /\left(F_{\max }-F\right)$. The maximal Fura-2 fluorescence intensity $\left(F_{\max }\right)$ was determined by adding $5 \mu \mathrm{M}$ ionomycin and the minimal fluorescence $\left(F_{\min }\right)$ was determined by quenching Fura-2 fluorescence with 5 $\mathrm{mM}$ EGTA plus $20 \mathrm{mM}$ Tris-base, $\mathrm{pH} 8.5$ and $0.1 \%$ Triton X-100 to lyse the cells.

${ }^{45} \mathrm{Ca}^{2+}$ uptake was determined as described by Eimerl and Schramm (1993). After incubation with glutamate, cells were washed twice with $\mathrm{Na}^{+}$medium $(140 \mathrm{mM} \mathrm{NaCl}, 5 \mathrm{mM} \mathrm{KCl}, 5 \mathrm{mM} \mathrm{MgCl}, 5 \mathrm{mM}$ $\mathrm{KH}_{2} \mathrm{PO}_{4}, 20 \mathrm{mM}$ Hepes-Na, $1.5 \mathrm{mM} \mathrm{CaCl}, \mathrm{pH} 7.4$ ) and then incubated in $2 \mathrm{ml} \mathrm{Na}^{+}$medium containing 1.0 $\mathrm{mM}$ unlabeled $\mathrm{CaCl}_{2}$ and $1.5 \mu \mathrm{Ci} / \mathrm{ml}^{45} \mathrm{Ca}^{2+}$ for $10 \mathrm{~min}$ at $37^{\circ} \mathrm{C}$. The incubation was stopped by rapidly washing the monolayers twice with ice-cold $\mathrm{Na}^{+}$medium $\left(140 \mathrm{mM} \mathrm{NaCl}, 5 \mathrm{mM} \mathrm{KCl}, 5 \mathrm{mM} \mathrm{MgCl}_{2}, 20 \mathrm{mM}\right.$ Hepes-Na, $1.5 \mathrm{mM} \mathrm{CaCl}_{2}$, pH 7.4) supplemented with 1 $\mathrm{mM} \mathrm{LaCl}{ }_{3}$ and finally once with ice-cold $\mathrm{Na}^{+}$medium supplemented with $\mathrm{LaCl}_{3}$ and also with $1 \mathrm{mM}$ EGTA, followed by addition of $0.1 \mathrm{M} \mathrm{NaOH}$. Aliquots of the cell digests were used for liquid scintillation counting and for protein determination (Sedmak and Grossberg, 1977).

\subsection{Quantification of endogenous GSH levels}

Cellular levels of GSH were determined using a GSH-400 colorimetric assay kit. PC12 cells were grown for $24-48 \mathrm{~h}$ before being incubated with glutamate $(0.5$ or $10 \mathrm{mM}$ ) for different periods of time. The medium was then discarded and the cells were washed twice in PBS, resuspended in $400 \mu \mathrm{l}$ of $5 \%$ (w/v) metaphospho- 
ric acid (MPA) and finally they were scraped and centrifuged. The assay was performed on 200- $\mu 1$ aliquots of centrifugation supernatants $\left(3000 \times g, 4^{\circ} \mathrm{C}\right.$, $10 \mathrm{~min}$ ), according to the manufacturer's instructions. The pellets were resuspended in $200 \mu$ of lysis buffer for subsequent protein determination by the Biuret method (Layne, 1957).

\subsection{Data analysis}

Throughout the text, data are expressed as means \pm S.E.M. of triplicate determinations, from at least three independent experiments. Statistical significance analysis was determined using the two-tailed unpaired Student's $t$-test or analysis of variance (ANOVA) for multiple comparisons, followed by the Turkey-Kramer posthoc test $(P<0.05$ was considered significant).

\section{Results}

\subsection{Antioxidants protect PC12 cells against glutamate-induced toxicity}

The dose-dependent glutamate toxicity was evaluated by determining the percentage of MTT reduction upon

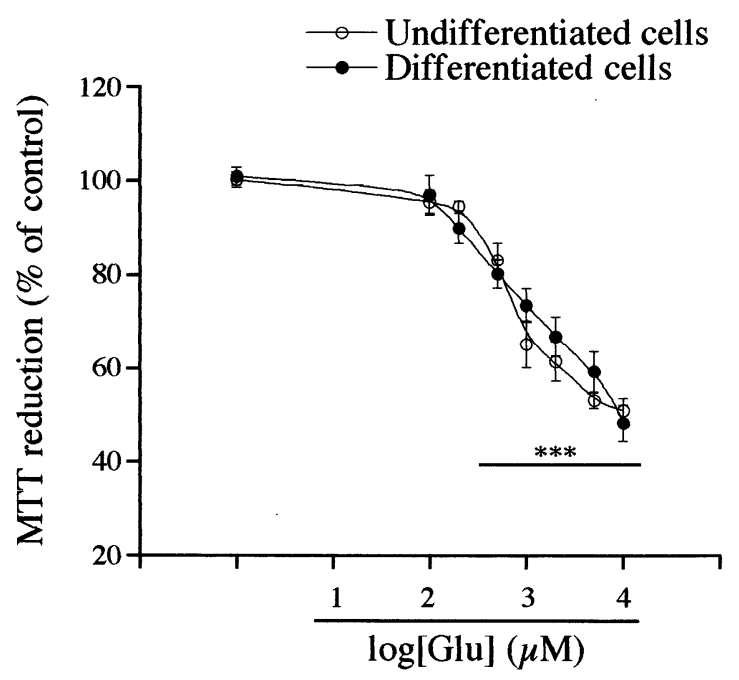

Fig. 1. Dose-response curve of the effect of glutamate on the viability of undifferentiated and differentiated PC12 cells. Cells, plated and grown for $24 \mathrm{~h}$ in culture medium, or cells differentiated in the presence of NGF plus dbcAMP for 7 days, were switched to fresh medium in the absence or in the presence of increasing glutamate concentrations $(0.1-10 \mathrm{mM})$. The reduction of the tetrazolium salt MTT were assessed $24 \mathrm{~h}$ later. The results, are the means \pm S.E.M. of triplicate determinations in 5-24 distinct experiments. ${ }^{* * *} P<0.001$, significantly different compared to control conditions, in the absence of glutamate.

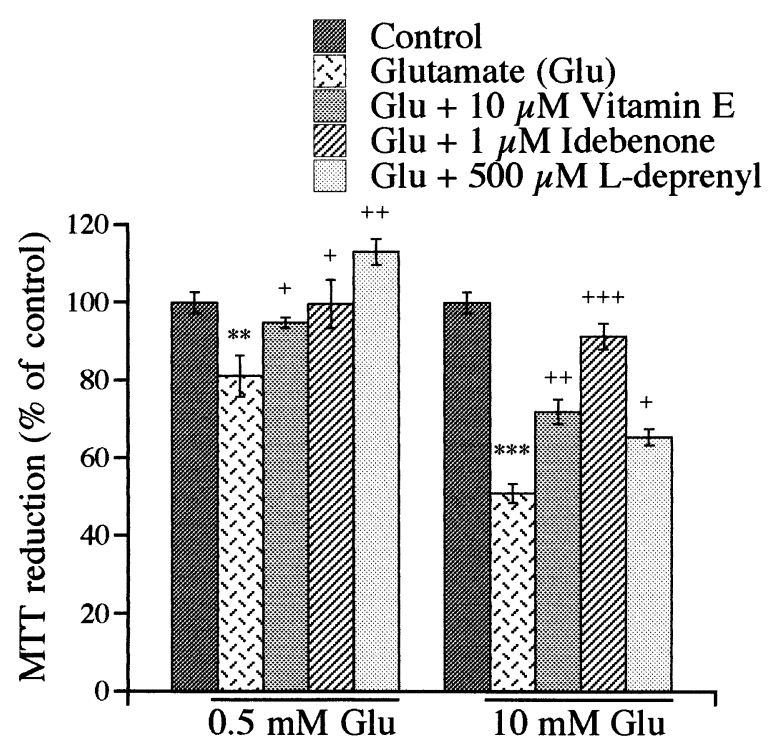

Fig. 2. Effect of the antioxidants vitamin E, idebenone and Ldeprenyl on glutamate-induced toxicity. Cells were plated and grown for $24 \mathrm{~h}$ in culture medium; they were then switched to fresh medium in the presence of 0.5 or $10 \mathrm{mM}$ glutamate. Cells were preincubated for $24 \mathrm{~h}$ with $10 \mu \mathrm{M}$ vitamin $\mathrm{E}$ or $1 \mu \mathrm{M}$ idebenone. Simultaneously with glutamate incubation, the antioxidants $(10 \mu \mathrm{M}$ vitamin $\mathrm{E}, 1 \mu \mathrm{M}$ idebenone and $500 \mu \mathrm{M}$ L-deprenyl) were added and the percentage of MTT reduction was assessed $24 \mathrm{~h}$ after glutamate addition. The results are the means \pm S.E.M. of triplicate determinations in 3-18 distinct experiments. ${ }^{* *} P<0.01,{ }^{* * *} P<0.001$, significantly different compared to control conditions, in the absence of glutamate, at the same incubation period. ${ }^{+} P<0.05,{ }^{+}+P<0.01,+++P<0.001$, significantly different compared to glutamate-treated control, in the absence of antioxidants.

incubation of differentiated and non-differentiated PC12 cells for $24 \mathrm{~h}$ with increasing glutamate concentrations in the range $0.1-10 \mathrm{mM}$. As shown in Fig. 1, increasing glutamate concentrations induced a decrease in cellular viability in a dose-dependent manner, both in untreated and NGF plus dbcAMP-treated PC12 cells, with a significant decrease of MTT reduction ability measured after incubation of the cells with $0.5 \mathrm{mM}$ glutamate.

The protective effect of several antioxidants with different mechanisms of action, namely vitamin E, idebenone and L-deprenyl, on the toxic effects of glutamate induced by the incubation with this amino acid for $24 \mathrm{~h}$ was tested (Fig. 2). Idebenone completely protected PC12 cells from cell damage induced by incubation with $0.5 \mathrm{mM}$ or $10 \mathrm{mM}$ glutamate. Also, L-deprenyl induced a great protection against $0.5 \mathrm{mM}$ glutamate-induced toxicity, while the protection exerted against $10 \mathrm{mM}$ glutamate was only partial, although it was significant (an increase of approximately 15\% in cellular viability was observed). Vitamin $\mathrm{E}$ also protected PC12 cells against the glutamate-induced decrease in cellular viability (MTT reduction in cells incubated with $0.5 \mathrm{mM}$ glutamate in the presence of vitamin $\mathrm{E}$ was similar to that in control cells while in 
cells exposed to $10 \mathrm{mM}$ glutamate, this antioxidant increased the reduction of MTT by about 25\%).

\subsection{High glutamate concentrations induce the accumulation of ROS}

To clarify the involvement of oxygen radicals in

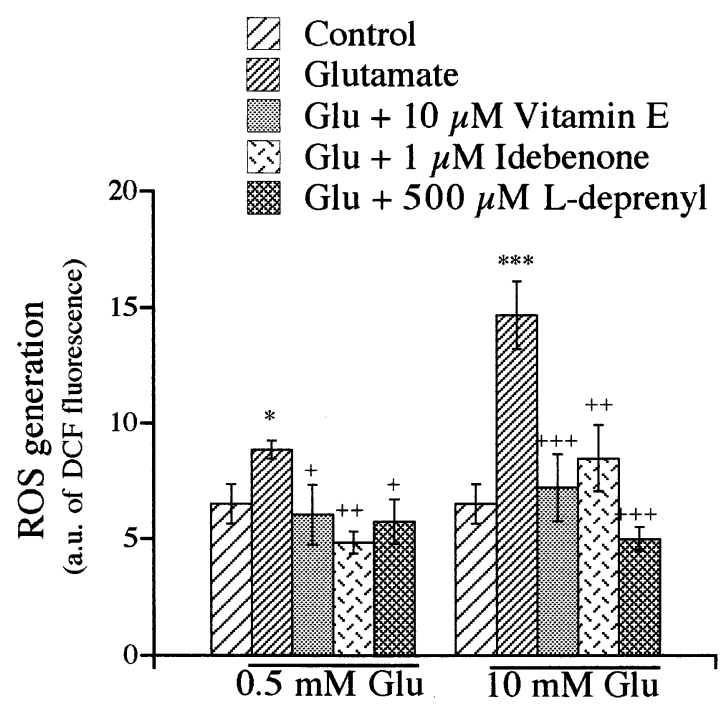

Fig. 3. Glutamate-stimulated intracellular accumulation of ROS in PC12 cells. Formation of ROS after $24 \mathrm{~h}$ of glutamate exposure was detected using $2^{\prime}, 7^{\prime}$-dichlorofluorescin diacetate oxidation and fluorescence. PC12 cells were cultured for $24 \mathrm{~h}$ in standard RPMI 1640 medium with 0.5 or $10 \mathrm{mM}$ glutamate or with glutamate $(0.5$ or 10 $\mathrm{mM})$ plus either vitamin $\mathrm{E}(10 \mu \mathrm{M})$, idebenone $(1 \mu \mathrm{M})$ and $\mathrm{L}$ deprenyl $(500 \mu \mathrm{M})$. Vitamin $\mathrm{E}$ and idebenone were added for preincubation, in the absence of glutamate, during $24 \mathrm{~h}$. The rate of DCF formation was then evaluated as described in Section 2. The results, expressed as arbitrary units of DCF fluorescence, are the means \pm S.E.M. of triplicate determinations in 3-11 distinct experiments. ${ }^{*} P<0.05,{ }^{* * *} P<0.001$, significantly different compared to control conditions, in the absence of glutamate. ${ }^{+} P<0.05,++P<0.01$, $+++P<0.001$, significantly different compared to glutamate-treated control, in the absence of antioxidants.

Table 1

Effect of glutamate on mitochondrial membrane potential (Rh123 retention $)^{\mathrm{a}}$

\begin{tabular}{lc}
\hline [Glutamate] $(\mathrm{mM})$ & Rh123 retention $(\%$ of control) \\
\hline 0 & $100.02 \pm 0.87$ \\
0.5 & $25.88 \pm 2.42^{*}$ \\
10 & $16.50 \pm 0.32^{* *}$
\end{tabular}

\footnotetext{
${ }^{a}$ Mitochondrial membrane potential was evaluated by the capacity of the cells to take up the fluorescent cationic dye Rh23, following cell incubation in the absence or presence of glutamate during $24 \mathrm{~h}$. Results are expressed as the percentage of Rh123 fluorescence remaining trapped by the cells, relative to control conditions, and are means \pm S.E.M. of 3-7 different experiments.

$* P<0.05$ significantly different compared to control conditions, in the absence of glutamate.

** $P<0.01$, significantly different compared to control conditions, in the absence of glutamate.
}

glutamate-induced toxicity in PC12 cells we have measured the accumulation of ROS after glutamate exposure, utilizing a converting reaction of $\mathrm{DCFH}_{2}-\mathrm{DA}$ to DCF (Fig. 3). ROS accumulation, determined by the measurement of DCF fluorescence (expressed in arbitrary units) was increased 1.4- and 2.3-fold after treatment with 0.5 and $10 \mathrm{mM}$ glutamate, respectively, in comparison with untreated controls. In the presence of antioxidants, the increased ROS accumulation induced by glutamate was clearly suppressed (Fig. 3). The DCF fluorescence determined after incubation of cells with 0.5 or $10 \mathrm{mM}$ glutamate, in the presence of vitamin $\mathrm{E}$, idebenone and L-deprenyl, was similar to that determined in control cells, incubated in the absence of glutamate.

\subsection{Glutamate leads to the impairment of mitochondrial function in PC12 cells}

The decrease of the mitochondrial membrane potential induced by glutamate was evaluated by determining the cellular retention of Rh123, which is known to be selectively taken up by mitochondria and to reflect the maintenance of the mitochondrial potential. As shown in Table 1, treatment of PC12 cells with cytotoxic doses of glutamate $(0.5$ and $10 \mathrm{mM})$, leads to a significant drop of Rh123 retention.

The determination of the intracellular ATP, ADP and AMP levels of PC12 cells, incubated for $24 \mathrm{~h}$ in the presence or in the absence of high glutamate concentrations $(0.5$ and $10 \mathrm{mM})$, was also used to demonstrate that the mitochondrial function is severely impaired by glutamate. It was observed that glutamate, at the concentrations tested $(0.5$ and $10 \mathrm{mM})$, was able to reduce significantly the ATP levels of the cells, which decreased to approximately 72 and $53 \%$ of control values, respectively (Table 2 ).

\subsection{The intracellular $\mathrm{Ca}^{2+}$ homeostasis in PC12 cells is perturbed by glutamate-induced oxidative stress}

Basal levels of $\left[\mathrm{Ca}^{2+}\right]_{i}$, measured in Fura-2-loaded cells, were increased in a time-dependent manner in cells treated with 0.5 and $10 \mathrm{mM}$ glutamate. A significant increase in the intracellular $\mathrm{Ca}^{2+}$ concentration, in comparison with controls, was observed after exposure of the cells for $12 \mathrm{~h}$ to glutamate (Fig. 4A).

The uptake of ${ }^{45} \mathrm{Ca}^{2+}$, was not significantly affected by treatment of PC12 cells with toxic concentrations of glutamate (Table 3 ).

\subsection{Glutamate decreases GSH levels}

The time-course analysis of GSH depletion shows that the endogenous levels of this cellular thiol are 
Table 2

Effect of glutamate on the intracellular levels of adenine nucleotides ${ }^{\mathrm{a}}$

\begin{tabular}{lccc}
\hline [Glutamate] $(\mathrm{mM})$ & ATP (nmol/mg protein) & ADP (nmol/mg protein) & AMP (nmol/mg protein) \\
\hline 0 & $16.005 \pm 1.404$ & $1.254 \pm 0.143$ & $1.475 \pm 0.168$ \\
0.5 & $11.507 \pm 1.205^{*}$ & $1.423 \pm 0.03^{*}$ & $1.160 \pm 0.112$ \\
10 & $8.413 \pm 0.794^{* *}$ & $1.761 \pm 0.245^{*}$ & $1.002 \pm 0.118$ \\
\hline
\end{tabular}

\footnotetext{
a After incubation during $24 \mathrm{~h}$, in the presence or absence of glutamate $(0.5$ or $10 \mathrm{mM})$, PC12 cells were extracted with perchloric acid and the resulting supernatants were assayed for adenine nucleotides by separation in a reverse-phase HPLC, as described in Section 2.

${ }^{*} P<0.05$, significantly different compared to control conditions, in the absence of glutamate, in the same incubation period.

** $P<0.01$, significantly different compared to control conditions, in the absence of glutamate, in the same incubation period.
}

significantly decreased after a 6-h incubation period in the presence of 0.5 or $10 \mathrm{mM}$ glutamate (Fig. 4B). The depletion of GSH was shown to occur earlier than the observed increase in the intracellular $\mathrm{Ca}^{2+}$ levels (Fig. 4A).

\section{Discussion}

We have previously demonstrated that: glutamate is toxic to PC12 cells in a dose- and time-dependent manner, as determined by the leakage of $\mathrm{LDH}$; glutamate-induced cell death results from the inhibition of cystine uptake and depletion of intracellular GSH levels; oxidative stress seems to be responsible for the toxicity, since several antioxidants were shown to be protective against glutamate-induced LDH leakage (Pereira and Oliveira, 1997). Furthermore, we have shown that glutamate toxicity is independent of the activation of NMDA or non-NMDA glutamate receptors (Pereira et al., 1998). The purpose of this work was to further define cytotoxic oxidative stress on PC12 cells.

The results we have obtained demonstrate that glutamate decreases the viability of PC12 cells, as determined by the MTT reduction assay (Fig. 1) and that several antioxidants protect cells against glutamate-induced inhibition of MTT reduction (Fig. 2), further supporting the hypothesis that oxidative stress is involved in glutamate toxicity.

The peroxide-sensitive dye DCF, which has the advantage of providing insight into total cytosolic ROS levels, was used to document that glutamate induced the accumulation of ROS in PC12 cells. A significant increase in hydroperoxides accumulation, evaluated as an increased rate of DCF formation, could be seen 24 $\mathrm{h}$ after glutamate treatment, several antioxidants being able to prevent this effect of glutamate (Fig. 3). The protective actions of antioxidants are not mediated by the recovery of cellular GSH levels, as demonstrated by our previous finding that vitamin $\mathrm{E}$, idebenone and L-deprenyl did not affect the decreased GSH levels produced by glutamate (Pereira and Oliveira, 1997). However, these compounds inhibit glutamate-induced
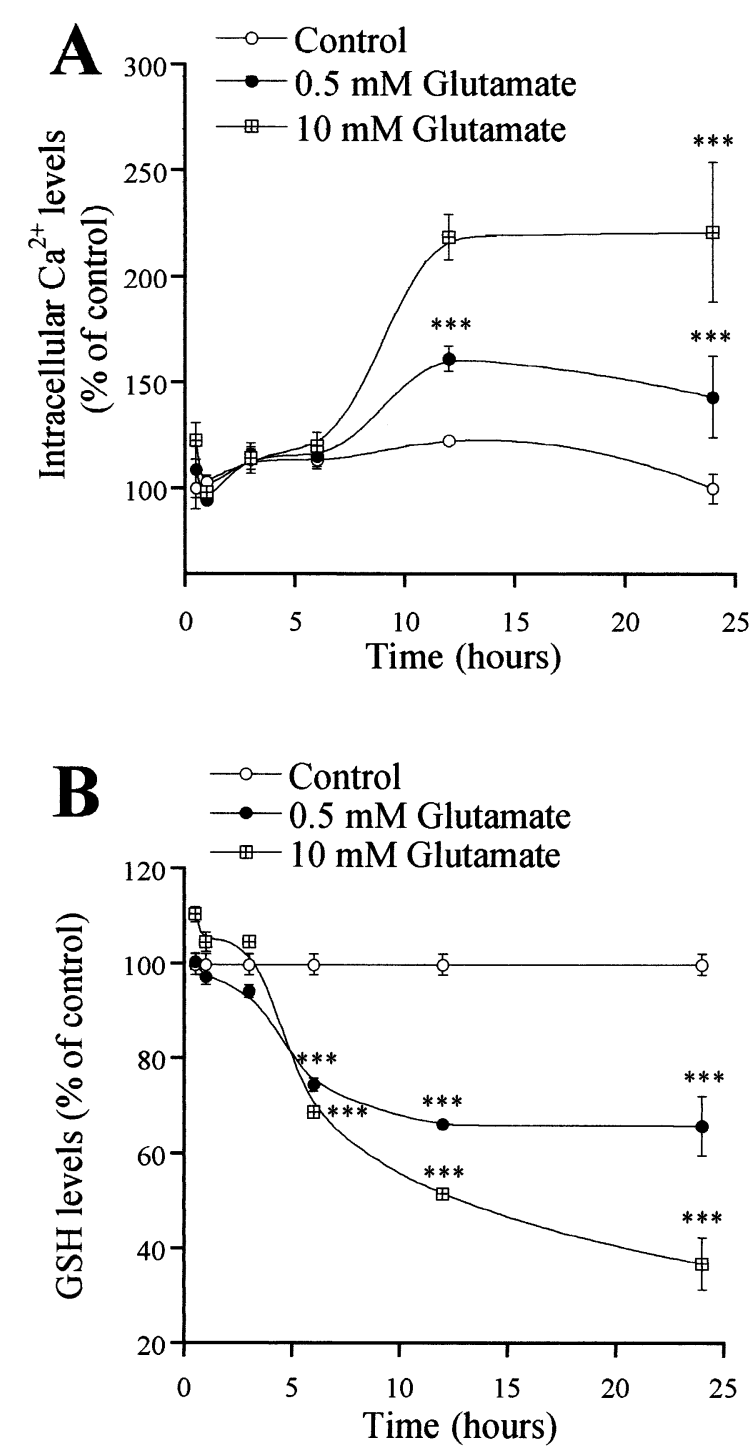

Fig. 4. Time-course of increase of intracellular $\mathrm{Ca}^{2+}$ levels (A) and GSH depletion (B) induced by glutamate treatment. $\left[\mathrm{Ca}^{2+}\right]_{\mathrm{i}}$ and GSH levels were measured, as described in Section 2, after incubation with 0.5 or $10 \mathrm{mM}$ glutamate for $30 \mathrm{~min}, 1,3,6,12$ or $24 \mathrm{~h}$. Results, expressed as the percentage of increase of $\left[\mathrm{Ca}^{2+}\right]_{\mathrm{i}}$ or decrease of GSH levels relative to controls, correspond to the means \pm S.E.M. of triplicate determinations in three distinct experiments. ${ }^{* *} P<0.01$; ${ }^{* * *} P<0.001$, significantly different compared to control conditions, in the absence of glutamate. 
Table 3

Effect of glutamate on the ${ }^{45} \mathrm{Ca}^{2+}$ uptake by $\mathrm{PC} 12$ cells ${ }^{\mathrm{a}}$

\begin{tabular}{lr}
\hline [Glutamate] $(\mathrm{mM})$ & ${ }^{45} \mathrm{Ca}^{2+}$ uptake $(\%$ of control $)$ \\
\hline 0 & $100 \pm 3.36$ \\
0.5 & $98.66 \pm 7.93$ \\
10 & $87.1 \pm 8.07$
\end{tabular}

${ }^{\text {a }}$ Uptake of ${ }^{45} \mathrm{Ca}^{2+}$ by PC12 cells after exposure for $24 \mathrm{~h}$ to 0.5 or $10 \mathrm{mM}$ glutamate was determined in the presence of $1 \mathrm{mM}$ unlabeled $\mathrm{CaCl}_{2}$ and $1.5 \mu \mathrm{Ci} / \mathrm{ml}^{45} \mathrm{Ca}^{2+}$ for $10 \mathrm{~min}$ at $37^{\circ} \mathrm{C}$, as described in Section 2. Values are the means \pm S.E.M. of triplicate determinations in six distinct experiments.

stimulation of peroxide accumulation (Fig. 3), which implies that the antioxidants directly protect the cells from the glutamate-induced cytotoxicity through the inhibition of peroxide formation or lipid peroxidation, in spite of the depletion of GSH. Decreased levels of GSH may lower the capacity of the cells to scavenge $\mathrm{H}_{2} \mathrm{O}_{2}$, released during normal dopamine metabolism, enhancing oxidative stress, disturbance of cellular function, and eventually leading to cell death (Spina and Cohen, 1989). The observed protection afforded against glutamate-induced toxicity by L-deprenyl, an inhibitor of the oxidative deamination of dopamine (Gerlach et al., 1992), suggests a role for monoamines in glutamate toxicity in this rat pheochromocytomaderived cell line.

The results here presented show that glutamate decreases the mitochondrial transmembrane potential, resulting in the reduction of mitochondrial retention of Rh123 (Table 1), which supports the hypothesis that glutamate induces mitochondrial dysfunction in PC12 cells. The loss of the mitochondrial transmembrane potential, induced by glutamate, may be caused, at least in part, by an increase in peroxide accumulation. Several groups have similarly noticed impairment in the mitochondrial membrane potential under oxidative stress conditions, caused by the increased generation of oxygen free radicals (Carini et al., 1992; Sastre et al., 1996; Vimard et al., 1996; Kruidering et al., 1997). The determination of the intracellular ATP, ADP and AMP levels of PC12 cells, incubated for $24 \mathrm{~h}$ in the presence or in the absence of high glutamate concentrations, also supported the conclusion that the mitochondrial function is severely impaired by glutamate. It was demonstrated that glutamate, at the concentrations tested $(0.5$ and $10 \mathrm{mM})$, was able to reduce significantly the ATP levels of the cells (Table 2). The high activity of glycolysis to support ATP synthesis in this cell line (Pereira et al., 1998) may be responsible for the maintenance of ATP levels above a certain threshold when the cells were incubated in the presence of $0.5 \mathrm{mM}$ glutamate. In the presence of high doses of glutamate $(10 \mathrm{mM})$, the extensive alterations of mitochondria, probably due to lipid peroxidation, do not allow the recovery of ATP levels by the glycolytic pathway.

The oxidative stress-induced drop in mitochondrial membrane potential has been demonstrated to be associated with $\mathrm{Ca}^{2+}$ ion leakage from these organelles (Lötscher et al., 1980; Nishida et al., 1989; Van de Water et al., 1994), which could probably explain the increase in intracellular $\mathrm{Ca}^{2+}$ levels observed after glutamate exposure (Fig. 4A). Under oxidative stress conditions, $\mathrm{Ca}^{2+}$ leakage is associated with the reuptake of the ion by the electrogenic uniport system, and the resulting $\mathrm{Ca}^{2+}$ cycling causes energy dissipation with the fall in membrane potential and a blocking of ATP resynthesis (Richter, 1997). As mentioned above, a significant reduction of the intracellular ATP levels was observed in cells exposed to high glutamate concentrations $(0.5$ and $10 \mathrm{mM})$ during $24 \mathrm{~h}$ (Table 2). The increased intracellular levels of free $\mathrm{Ca}^{2+}$, observed after treatment of PC12 cells with high doses of glutamate (Fig. 4A), suggest a role for $\mathrm{Ca}^{2+}$ in glutamate-induced cell death. With decreased levels of GSH, the ability of the cells to scavenge free radicals formed by $\mathrm{Ca}^{2+}$-dependent pathways, i.e. lipooxygenases and phospholipases (Baba et al., 1986) may be impaired. Consistent with this interpretation, the lipooxygenase inhibitors and phospholipase A2 inhibitors reduce the cytotoxicity of glutamate in N18RE-105 cells, although they did not protect the depletion of GSH levels (Murphy et al., 1989). The observed protective effects of divalent metals against low-cystine-type cell death and glutamate-induced cell death (Murphy et al., 1988) suggest that intracellular oxidants may be able to produce prolonged activation of voltage-sensitive $\mathrm{Ca}^{2+}$ channels. The activity of voltage-dependent $\mathrm{Ca}^{2+}$ channels and other $\mathrm{Ca}^{2+}$ uptake systems, known to be sensitive to oxidation (Reeves et al., 1986; Roveri et al., 1992; Rohn et al., 1993; Pereira et al., 1996), does not seem to be compromised under our experimental conditions because the uptake of calcium was not significantly different in control and glutamate-treated cells (Table 3 ). The increase in intracellular $\mathrm{Ca}^{2+}$ levels could result from the impairment of plasma membrane extrusion mechanisms, inhibition of sequestration by intracellular organelles or from the release of $\mathrm{Ca}^{2+}$ from intracellular stores. Previous studies of liver cells demonstrated that prooxidants are able to impair mitochondrial function leading to $\mathrm{Ca}^{2+}$ release from mitochondria (Richter and Schlegel, 1993). Therefore, the contribution of mitochondrial dysfunction induced by glutamate on PC12 cells, to the increased $\left[\mathrm{Ca}^{2+}\right]_{i}$ cannot be ruled out.

It has been reported that depletion of cellular GSH is cytotoxic when followed by a decline in cellular energy status (Redegeld et al., 1992). Depletion of mitochondrial GSH, imported from the cytosol 
(Griffith and Meister, 1985), may result in impaired mitochondrial function (Heales et al., 1995), since all the complexes of the electron transport chain are reported to be susceptible to damage by oxygen free radicals, in vitro (Benzi and Moretti, 1995). The work of Nishikawa et al. (1997) demonstrated that cytosolic GSH rather than intramitochondrial GSH, might be an important factor stabilizing the energy metabolism of mitochondria. Bolaños et al. (1996) showed that reduced GSH may be an important defense against the damage to the neuronal mitochondrial respiratory chain induced by sustained exposure to free radicals. The depletion of GSH, induced by glutamate exposure (Fig. 4B), might be involved in the impairment of energy metabolism observed under our experimental conditions, the decrease of the endogenous levels of GSH preceding ROS accumulation and mitochondrial dysfunction. Recently, we have shown that oxidative stress conditions, which lead to GSH depletion, induce impairment of mitochondrial function (Cardoso et al., 1998, 1999). Furthermore, the depletion of GSH prior to the increase of intracellular $\mathrm{Ca}^{2+}$ levels, supports the hypothesis that ROS contribute to the disturbance of $\mathrm{Ca}^{2+}$ homeostasis. Jurma et al. (1997) observed that in PC12 cells depleted of GSH, the increased cell loss appeared to be due to increased levels of ROS and a subsequent rise of $\mathrm{Ca}^{2+}$ levels. It should be noted that neuronal injury, resulting from hydrogen peroxide exposure, can be mimicked in PC12 cells by treatment with the calcium ionophore ionomycin, suggesting that ROS may indeed elicit their destructive effects in PC12 cells via disruption of intracellular calcium homeostasis (Hinshaw et al., 1993).

In conclusion, we have shown that oxidative glutamate toxicity leads to mitochondrial dysfunction and that it can probably be responsible for the leakage of $\mathrm{Ca}^{2+}$ ions from the mitochondria, increasing its intracellular concentration. The impairment of mitochondrial function and perturbation of calcium homeostasis can help to elucidate the mechanisms of glutamate-induced oxidative stress and cell death in PC12 cells. Furthermore, the data presented in this study suggest that the decreased cell survival is due to apoptotic cell death since it has been described that apoptosis is characterized by depolarization of mitochondrial membrane (Kroemer et al., 1997), generation of ROS and increase of intracellular calcium levels (Kruman et al., 1998), which have been observed upon exposure of PC12 cells to glutamate.

\section{Acknowledgements}

The present work was supported by FCT (Portuguese Research Council) and the Human Capital Mobility Program (EU), Proposal no.: ERB 4050 PL
932039. Cláudia Pereira is a recipient of grant PRAXIS XXI/BD/3889/94. We thank Dr Maria Sancha Santos (Center for Neuroscience of Coimbra, Department of Zoology, University of Coimbra) for helpful assistance in the quantification of adenine nucleotides by HPLC.

\section{References}

Baba, A., Onoe, H., Ohta, A., Iwata, H., 1986. Assay of phospholipase A2 activity of synaptic membranes using a phospholipid transfer protein: stimulation by depolarization. Biochim. Biophys. Acta 878, 25-31.

Bannai, S., 1986. Exchange of cystine and glutamate across plasma membrane of human fibroblasts. J. Biol. Chem. 261, 22562263.

Bass, D.A., Parce, J.W., Dechatelet, L.R., Szejda, P., Seeds, M.C., Thomas, M., 1983. Flow cytometric studies of oxidative product formation by neutrophils: a graded response to membrane stimulation. J. Immunol. 130, 1910-1917.

Behl, C., Widmann, M., Trapp, T., Holsboer, F., 1992. 17- $\beta$ Estradiol protects neurons from oxidative stress-induced cell death in vitro. Biochem. Biophys. Res. Commun. 216, 473-482.

Behl, C., Lezoulac'h, F., Trapp, T., Widmann, M., Skutella, T., Holsboer, F., 1997. Glucocorticoids enhance oxidative stress-induced cell death in hippocampal neurons in vitro. Endocrinology 138, 101-106.

Benzi, G., Moretti, A., 1995. Age- and peroxidative stress-related modifications of the cerebral enzymatic activities linked to mitochondria and the glutathione system. Free Radic. Biol. Med. 19, 77-101.

Blandini, F., Porter, R.H.P., Greenamyre, J.T., 1996. Glutamate and Parkinson's disease. Mol. Neurobiol. 12, 73-94.

Bolaños, J.P.V., Heales, S.J.R., Peuchen, S., Barker, J.E., Land, J.M., Clark, J.B., 1996. Nitric oxide-mediated mitochondrial damage: a possible neuroprotective role for glutathione. Free Radic. Biol. Med. 21, 995-1001.

Bolaños, J.P., Almeida, A., Stewart, V., Peuchen, S., Land, J.M., Clark, J.B., Heales, S.J.R., 1997. Nitric oxide-mediated mitochondrial damage in the brain: mechanisms and implications for neurodegenerative diseases. J. Neurochem. 68, 2227-2240.

Calderón, F.H., Bonnefont, A., Muñoz, F.J., Fernández, V., Videla, L.A., Inestrosa, N.C., 1999. PC12 and Neuro 2a cells have different susceptibilities to acetylcholinesterase-amyloid complexes, amyloid ${ }_{25-35}$ fragment, glutamate, and hydrogen peroxide. J. Neurosci. Res. 56, 620-631.

Cardoso, S.M., Pereira, C., Oliveira, C.R., 1998. The protective effect of vitamin E, idebenone and reduced glutathione on free radical mediated injury in rat brain synaptosomes. Biochem. Biophys. Res. Commun. 246, 703-710.

Cardoso, S.M., Pereira, C., Oliveira, C.R., 1999. Mitochondrial function is differentially affected upon oxidative stress. Free Radic. Biol. Med. 26, 3-13.

Carini, R., Parola, M., Dianzani, M.U., Albano, E., 1992. Mitochondrial damage and its role in causing hepatocyte injury during stimulation of lipid peroxidation by iron nitriloacetate. Arch. Biochem. Biophys. 297, 110-118.

Coyle, J.T., Puttfarcken, P.S., 1993. Oxidative stress, glutamate and neurodegenerative disorders. Science 262, 689-694.

Davis, J.B., Maher, P., 1994. Protein kinase C activation inhibits glutamate-induced cytotoxicity in a neuronal cell line. Brain Res. 652, 169-173. 
Di Virgilio, F., Meyer, B.C., Greenberg, S., Silverstein, S.C., 1988. Fc receptor-mediated phagocytosis occurs in macrophages at exceeding low cytosolic $\mathrm{Ca}^{2+}$ levels. J. Biol. Chem. 106, 657-666.

Eimerl, S., Schramm, M., 1993. Potentiation of ${ }^{45} \mathrm{Ca}$ uptake and acute toxicity mediated by the $\mathrm{N}$-methyl-D-aspartate receptor: the effect of metal binding agents and transition metal ions. J. Neurochem. 61, 518-525.

Froissard, P., Duval, D., 1994. Cytotoxic effects of glutamic acid on PC12 cells. Neurochem. Int. 24, 485-493.

Gerlach, M., Riederer, P., Youdim, M.B.H., 1992. The molecular pharmacology of L-deprenyl. Eur. J. Pharmacol. 226, 97-108.

Greene, L.A., Rein, G., 1977. Release, storage and uptake of catecholamines by a clonal cell line of nerve growth factor (NGF) responsive pheochromocytoma cells. Brain Res. 129, 247-263.

Greene, L.A., Tischler, A.S., 1976. Establishment of a noradrenergic clonal line of rat adrenal pheochromocytoma cells which respond to nerve growth factor. Proc. Natl. Acad. Sci. USA 73, 2424 2428.

Griffith, O.W., Meister, A., 1985. Origin and turnover of mitochondrial glutathione. Proc. Natl. Acad. Sci. USA 82, 4668-4672.

Heales, S.J.R., Davies, S.E.C., Bates, T.E., Clark, J.B., 1995. Depletion of brain glutathione is accompanied by impaired mitochondrial function and decreased $\mathrm{N}$-acetylaspartate concentration. Neurochem. Res. 20, 31-38.

Hinshaw, D.B., Miller, M.T., Omann, G.M., Beal, T.F., Hyslop, P.A., 1993. A cellular model of oxidant-mediated neuronal injury. Brain Res. 615, 13-26.

Jenner, P., 1994. Oxidative damage in neurodegenerative diseases. Lancet 344, 796-798.

Jurma, O.P., Hom, D.G., Andersen, J.K., 1997. Decreased glutathione results in calcium-mediated cell death in PC12. Free Radic. Biol. Med. 23, 1055-1066.

Kato, S., Higashida, H., Higuchi, Y., Hatakenaka, S., Negishi, K., 1984. Sensitive and insensitive states of cultured glioma cells to glutamate damage. Brain Res. 303, 365-373.

Kato, S., Negishi, K., Mawatari, K., Kuo, C.-H., 1992. A mechanism for glutamate toxicity in the $\mathrm{C} 6$ glioma cells involving inhibition of cystine uptake leading to glutathione depletion. Neuroscience 48, 903-914.

Kehrer, J.P., 1993. Free radicals as mediators of tissue injury and disease. Crit. Rev. Toxicol. 23, 21-48.

Kroemer, G., Zamzami, N., Susin, S.A., 1997. Mitochondrial control of apoptosis. Immunol. Today 18, 44-51.

Kruidering, M., De Water, B.V., De Heer, E., Mulder, G.J., Nagelkerke, J.F., 1997. Cisplatin-induced nephrotoxicity in porcine proximal tubular cells: mitochondrial dysfunction by inhibition of complexes I to IV of the respiratory chain. J. Pharmacol. Exp. Ther. 280, 638-649.

Kruman, I., Guo, Q., Mattson, M.P., 1998. Calcium and reactive oxygen species mediate staurosporine-induced mitochondrial dysfunction and apoptosis in PC12 cells. J. Neurosci. Res. 51, 293-308.

Layne, E., 1957. Spectrophotometric and turbidimetric methods for measuring proteins. Methods Enzymol. 3, 447-451.

Lees, G.J., 1993. Contributory mechanisms in the causation of neurodegenerative diseases. Neuroscience 54, 287-322.

Liu, P.-S., Lin, Y.-J., Kao, L.-S., 1991. Caffeine-sensitive calcium stores in bovine chromaffin cells. J. Neurochem. 56, 172-177.

Lötscher, H.R., Winterhalter, K.H., Carafoli, E., Richter, C., 1980. Hydroperoxide-induced loss of pyridine nucleotides and release of calcium from rat liver mitochondria. J. Biol. Chem. 255, 93259330.

Maher, P., Davis, J.B., 1996. The role of monoamine metabolism in oxidative glutamate toxicity. J. Neurosci. 16, 6394-7401.

Michaels, R.L., Rothman, S.M., 1990. Glutamate neurotoxicity in vitro: antagonist pharmacology and intracellular calcium concentrations. J. Neurosci. 10, 283-292.
Miyamoto, M., Murphy, T.H., Schnaar, R.L., Coyle, J.T., 1989 Antioxidants protect against glutamate-induced cytotoxicity in a neuronal cell line. J. Pharmacol. Exp. Ther. 250, 1132-1140.

Mosmann, T., 1983. Rapid colorimetric assay for cellular growth and survival: application to proliferation and cytotoxicity assays. J. Immunol. Methods 65, 55-63.

Murphy, T.H., Schnaar, R.L., Coyle, J.T., Sastre, A., 1988. Glutamate cytotoxicity in a neuronal cell line is blocked by membrane depolarization. Brain Res. 460, 155-160.

Murphy, T.H., Miyamoto, M., Sastre, A., Schnaar, R.L., Coyle, J.T., 1989. Glutamate toxicity in a neuronal cell line involves inhibition of cystine transport leading to oxidative stress. Neuron 2, $1547-$ 1548.

Murphy, T.H., Schnaar, R.L., Coyle, J.T., 1990. Immature cortical neurons are uniquely sensitive to glutamate toxicity by inhibition of cystine uptake. FASEB J. 4, 1624-1633.

Nishida, T., Inoue, T., Kanike, W., Kawashima, Y., Tagawa, K., 1989. Involvement of $\mathrm{Ca}^{2+}$ release and activation of phospholipase A2 in mitochondrial dysfunction during anoxia. J. Biochem. $106,533-538$.

Nishikawa, M., Sato, E.F., Kuroki, T., Inoue, M., 1997. Role of glutathione and nitric oxide in the energy metabolism of rat liver mitochondria. FEBS Lett. 415, 341-345.

Obrenovitch, T.P., Urenjak, J., 1997. Altered glutamatergic transmission in neurological disorders: from high extracellular glutamate to excessive synaptic efficacy. Prog. Neurobiol. 51, 39-87.

Oka, A., Belliveau, M.J., Rosenberg, P.A., Volpe, J.J., 1993. Vulnerability of oligodendroglia to glutamate: pharmacology, mechanisms and prevention. J. Neurosci. 13, 1441-1453.

Olney, J.W., 1969. Brain lesions, obesity and other disturbances in mice treated with monosodium glutamate. Science 164, 719-721.

Palmeira, C.M., Moreno, A.J.M., Madeira, V.M.C., Wallace, K.B., 1996. Continuous monitoring of mitochondrial membrane potential in hepatocyte cell suspensions. J. Pharmacol. Toxicol. Methods $35,35-43$.

Pereira, C., Oliveira, C.R., 1997. Glutamate toxicity on a PC12 cell line involves GSH depletion and oxidative stress. Free Radic. Biol. Med. 23, 637-647.

Pereira, C., Ferreira, C., Carvalho, C., Oliveira, C., 1996. Contribution of plasma membrane and endoplasmic reticulum $\mathrm{Ca}^{2+}$-ATPases to the synaptosomal $\left[\mathrm{Ca}^{2+}\right]_{i}$ increase during oxidative stress. Brain Res. 713, 269-277.

Pereira, C., Santos, M.S., Oliveira, C.R., 1998. Metabolic inhibition increases glutamate susceptibility on a PC12 cell line. J. Neurosci. Res. 51, 360-370.

Redegeld, F.A.M., Moison, R.M.W., Koster, A.S., Noordhoek, J., 1992. Depletion of ATP but not of GSH affects viability of rat hepatocytes. Eur. J. Pharmacol. 228, 228-236.

Reeves, J.P., Bailey, C.A., Hale, C.C., 1986. Redox modification of sodium-calcium exchange activity in cardiac sarcolemmal vesicles. J. Biol. Chem. 261, 4948-4955.

Richter, C., 1997. Reactive oxygen and nitrogen species regulate mitochondrial $\mathrm{Ca}^{2+}$ homeostasis and respiration. Biosci. Rep. 17, $53-65$.

Richter, C., Schlegel, J., 1993. Mitochondrial calcium release induced by prooxidants. Toxicol. Lett. 67, 119-127.

Rohn, T.T., Hinds, T.R., Vincenzi, F.F., 1993. Ion transport ATPases as targets for free radical damage. Chem. Pharmacol. 46, 525-534.

Roveri, A., Coassin, M., Maiorino, M., Zamburlini, A., van Amsterdam, F.T.M., Ratti, E., Ursini, F., 1992. Effect of hydrogen peroxide on calcium homeostasis in smooth muscle cells. Arch. Biochem. Biophys. 297, 265-270.

Sastre, J., Pallardó, F.V., Plá, R., Pellín, A., Juan, G., O’Connor, J.E., Estrela, J.M., Miquel, J., Viña, J., 1996. Aging of the liver: age-associated mitochondrial damage in intact hepatocytes. Hepatology 24, 1199-1205. 
Schubert, D., Kimura, H., Maher, P., 1992. Growth factors and vitamin E modify neuronal glutamate toxicity. Proc. Natl. Acad. Sci. USA 89, 8264-8267.

Sedmak, J.J., Grossberg, S.E., 1977. A rapid sensitive and versatile assay for protein using Coomassie Brilliant Blue G 250. Anal. Biochem. 79, 544-552.

Spina, M.B., Cohen, G., 1989. Dopamine turnover and glutathione oxidation: implications for Parkinson's disease. Proc. Natl. Acad. Sci. USA 86, 1398-1400.

Stocchi, V., Cucchiarini, L., Palma, P., Crescentini, G., 1985. Simultaneous extraction and reverse-phase high-performance liquid chromatography determination of adenine and pyridine nucleotides in human red blood cells. Anal. Biochem. 146, 118124.
Van de Water, B., Zoeteweij, J.P., de Bont, H.J.G.M., Mulder, G.J., Nagelkerke, J.F., 1994. Role of mitochondrial $\mathrm{Ca}^{2+}$ in the oxidative stress-induced dissipation of the mitochondrial membrane potential. Studies in isolated proximal tubular cells using the nephrotoxin 1,2 dichlorovinyl L cysteine. J. Biol. Chem. 269, 14546-14552.

Vimard, F., Nouvelot, A., Duval, D., 1996. Cytotoxic effects of an oxidative stress on neuronal-like pheochromocytoma cells (PC12). Biochem. Pharmacol. 51, 1389-1395.

Vornov, J.J., Coyle, J.T., 1991. Glutamate neurotoxicity and the inhibition of protein synthesis in the hippocampal slice. J. Neurochem. 56, 996-1006.

Vrasenic, I., Knöpfel, T., 1991. Calculation of calcium dynamics from single wavelength fura-2 fluorescence recordings. Pflügers Arch. 418, $184-189$. 